Grafting in cucurbits is common in several

\title{
Influence of Grafted Watermelon Plant Density on Yield and Quality in Soil Infested with Melon Necrotic Spot Virus
}

\author{
María Victoria Huitrón-Ramírez \\ UNIDO/SEMARNAT, Instituto Tecnológico de Torreón, Coah, México
}

\author{
Marcia Ricárdez-Salinas \\ UNIDO/SEMARNAT, México
}

\section{Francisco Camacho-Ferre ${ }^{1}$ \\ Universidad de Almería, Producción Vegetal, Crta. Sacramento s/n, La Cañada de San Urbano, Almería 04120, Spain}

Additional index words. Citrullus lanatus, Cucurbita maxima $\times$ Cucurbita moschata, grafting, methyl bromide, rootstocks, soil pathogens

\begin{abstract}
One of the major problems of watermelon production is the decrease of fruit yield and quality caused by soil diseases. Soil disinfection with methyl bromide (MB) has been used to prevent fungus attacks; however, its use is being restricted because this substance damages the ozone layer. Searching for new MB alternatives, field experiments were carried out in open field in soils infested with Olpidium bornovanus and melon necrotic spot virus in Colima, Mexico, where watermelons had only been grown previously using soil fumigation with $\mathrm{MB}$. Yield and quality of watermelon cultivar triploid Tri-X 313 grafted on two rootstocks of Cucurbita maxima $\times$ Cucurbita moschata ('RS841' and 'Shintosa Camelforce') were evaluated during 2 consecutive years. Each experiment had five treatments, two of them with nongrafted plants at a density of 3472 plants/ha with and without MB fumigation. The remaining three treatments had grafted plants in nonfumigated soil with plant densities of 2778,2083 , and 1740 plants/ha. The use of watermelon grafted on 'RS841' and 'Shintosa Camelforce' rootstocks significantly increased the average fruit weight and the total yield of watermelon in soil without the need for $M B$. Grafting may be considered as an alternative MB fumigation. With the use of grafted watermelon plants, planting density may be reduced by $50 \%$, obtaining higher yields than those obtained from nongrafted plants grown on fumigated soil except for 'Tri-X 313' grafted on 'Shintosa Camelforce' in 2006-2007. Fruits harvested from grafted plants had higher firmness than those harvested from nongrafted plants without affecting the content of soluble solids.
\end{abstract}

Watermelon is one of the world's most important vegetables with a global production of $93.2 \mathrm{Mt}$ and an area of $3.60 \mathrm{M} \cdot \mathrm{ha}^{-1}$. Production has increased by $15 \%$ in the last 7 years. Mexico is one of the main producers of watermelon along with China, Turkey, United States, Egypt, Spain, and Korea. Furthermore, Mexico is one of the most important exporters of watermelon (FAOSTAT, 2007).

One of the great problems of watermelon is the decrease in fruit yield and quality caused by soil diseases, mainly Fusarium oxysporum f. sp. niveum; however, other pathogens such as Verticillium dahliae, Monosporascus cannonballus, Rhizoctonia solani, Meloidogyne incognita, and the melon necrotic spot virus (MNSV) also contribute to plant deterioration (Miguel, 2005).

There are different ways to prevent the attacks of soil pathogens to plants: crop rotation, genetic improvement, and soil fumiga-

Received for publication 24 July 2009. Accepted for publication 27 Aug. 2009.

${ }^{1}$ To whom reprint requests should be addressed; e-mail fcamacho@ual.es. tion (Alan et al., 2007; Rivero et al., 2003; Yetisir and Sari, 2004); however, each of these practices has inconveniences. The possibility of breeding new cultivars with resistance to diseases takes a long time and is very expensive (Passam, 2003). Breeding for resistance against some pathogens has been futile because the pathogen quickly overcomes resistance (Camacho and Fernández, 2000). The use of methyl bromide (MB) is very limited as a result of environmental contamination and high toxicity to humans (Passam, 2003). Fumigation with MB does not offer a solution against some soil diseases (Schneider et al. cited by Rivero et al., 2003).

Grafting vegetables has been used by several reasons, but the main one is the strong tolerance or resistance of rootstocks to some soil diseases such as fusarium, verticillium, nematodes (King et al., 2008, Lee, 2003; Passam, 2003), monosporascus, and MNSV (Boughalleb et al., 2007; Edelstein et al., 1999; Miguel, 2005; Siguenza et al., 2005). Grafting with resistant rootstocks offers one of the best ways to avoid soil diseases and improves growth under low temperature (Sakata et al., 2007).
Mediterranean countries, Asia, and Europe, but it is still an uncommon practice in North America (Besri, 2008; Lee, 2003). The interest in grafting has increased in other countries as MB becomes less available and more expensive, increasing the potential benefits of grafting (Cushman and Huan, 2008).

The added cost from using grafted plants is partly mitigated by the decrease in the required plant density (Camacho and Tello, 2006).

The United Nations Organization for Industrial Development together with the Secretaría de Medio Ambiente y Recursos Naturales (Environment and Natural Resources Secretariat) of Mexico have carried out demonstration and technology transfer projects demonstrating grafting vegetables as an alternative to $\mathrm{MB}$. The objective of this research was to evaluate the influence of two hybrid rootstocks and different planting densities on watermelon yield and quality in commercial watermelon fields. These grafted plants were compared with nongrafted checks with and without MB fumigation.

\section{Materials and Methods}

The experiments were carried in the southeast of the State of Colima in Mexico (long. $19.1^{\circ} \mathrm{N}$, lat. $103.6^{\circ} \mathrm{W}$ ) during fallwinter for 2 consecutive years in soil naturally infested with Olpidium bornovanus and MNSV. The soil was evaluated for pathogens at the Vegetal Pathology Laboratory of the University of Almería before doing the first planting and after the second year of cultivation.

The soil was a sandy loam with $1.72 \%$ organic matter, $\mathrm{pH}$ of 6.5 , and electric conductivity (EC) in the saturation extract of 0.9 $\mathrm{dS} \cdot \mathrm{m}^{-1}$. The physical and chemical properties of the irrigation water used were the following: pH 7.4, EC $0.9 \mathrm{dS} \cdot \mathrm{m}^{-1}, 0.38 \mathrm{mmol} \cdot \mathrm{L}^{-1} \mathrm{Ca}^{2+}$, $0.15 \mathrm{mmol} \cdot \mathrm{L}^{-1} \mathrm{Mg}^{2+}, 2.96 \mathrm{mmol} \cdot \mathrm{L}^{-1} \mathrm{Na}^{+}$, $2.0 \mathrm{mmol} \cdot \mathrm{L}^{-1} \mathrm{Cl}^{-1}$, and $2.2 \mathrm{mmol} \cdot \mathrm{L}^{-1}$ $\mathrm{HCO}^{-1}$. The nutrients were applied using the drip irrigation system at the following solution concentrations: $10 \mathrm{mmol} \cdot \mathrm{L}^{-1} \mathrm{NO}^{-}$, $2 \mathrm{mmol} \cdot \mathrm{L}^{-1} \mathrm{H} 2 \mathrm{PO} 4^{-}, 2 \mathrm{mmol} \cdot \mathrm{L}^{-1} \mathrm{SO}^{2-}$, $0.5 \mathrm{mmol} \cdot \mathrm{L}^{-1} \mathrm{HCO}^{-}, 8 \mathrm{mmol} \cdot \mathrm{L}^{-1} \mathrm{~K}^{+}$, $6 \mathrm{mmol} \cdot \mathrm{L}^{-1} \mathrm{Ca}^{2+}$, and $2 \mathrm{mmol} \cdot \mathrm{L}^{-1} \mathrm{Mg}^{2+}$.

The triploid watermelon cultivar Tri-X 313 was used along with the diploid cultivar Sangría as a pollenator. The interspecific hybrid rootstocks of Cucurbita maxima $\times$ Cucurbita moschata were 'RS841' and 'Shintosa Camelforce'. Watermelon seed was sown between 7 and $12 \mathrm{~d}$ before the rootstock seed in 200-cell trays with a volume of $25 \mathrm{~cm}^{3} /$ cell. Grafting was made when both rootstocks and scion had their first true leaves completely developed. The grafting method was the approach method (Camacho and Fernández, 2000; Davis et al., 2008; Hassell and Memmott, 2008; Lee and Oda, 2003; Passam, 2003) using a flexible metal strip to join the seedlings. The grafted plants were placed in 60 -cell trays with a volume of $150 \mathrm{~cm}^{3} /$ cell. The substrate used for germination and transplant was a 2:1 (v/v) mixture of peat and perlite. 
Experiments for each rootstock were independent. Experimental designs were randomized complete blocks with five treatments and four replications. Two treatments had nongrafted plants, one in nonfumigated soil and the other in a soil fumigated with $\mathrm{MB}$, but both of them with 3472 plants/ha (100\%). This is the conventional plant density used by producers in the region. The three remaining treatments had grafted plants and nonfumigated soil with 2778 (80\%), $2083(60 \%)$, and $1736(50 \%)$ plants/ha (Table 1).

All plants of all treatments were planted on $0.70-\mathrm{m}$ wide beds separated by $3.60 \mathrm{~m}$ between them (from middle to middle). Planted beds were covered with gray polyethylene plastic mulch.

In the experiments in which the rootstock 'RS841' was used, each experimental plot had six rows. In the experiments in which 'Shintosa Camelforce' was used, plots had four rows. In both cases, the length of the rows was $27 \mathrm{~m}$.

Transplanting was done on 24 Nov. 2006 (first year) and on 18 Nov. 2007 (second year). The ratio of triploid/diploid watermelon was 2:1 in the same row (Camacho and Fernández, 2000). The weed control was made manually and the pest and disease control was made through chemical and biological applications. Pollination was made with bees (Apis mellifera), which were introduced $25 \mathrm{~d}$ after transplanting with a stay of $33 \mathrm{~d}$ during the first year, whereas during the second year, they were introduced 36 $\mathrm{d}$ after transplanting and they were left for 45 d. In both cases, there were four beehives/ha.

The harvest was carried out by specialized professionals, who only harvested fruit with quality standards for marketing. During the first year, 11 harvests were carried out from 31 Jan. to 12 Apr. During the second year, eight harvests were carried out from 1 Feb. to 31 Mar. For each harvest, in every plot, all the harvested fruits were counted choosing five 'Tri-X 313' fruit and two 'Sangría' fruit to weigh and then estimating the yield from each fruit type and the total yield. Three measurements of the content of soluble solids and flesh firmness were conducted from fruits in each plot.

The data were subject to analysis of variance and means separation through Fisher's minimum significant difference test $(P<0.05)$ using the statistical program Statgraphics Plus 4.0 for Windows (Manugistic, Rockville, MD).

\section{Results and Discussion}

Two weeks after the harvest began, more than $90 \%$ of the plants from the nongrafted plants plots were wilting.

Table 1. Treatment description.

\begin{tabular}{lccc}
\hline & \multicolumn{3}{c}{ Description } \\
\cline { 2 - 4 } & $\begin{array}{c}\text { Soil disinfection } \\
\text { with methyl } \\
\text { bromide }\end{array}$ & $\begin{array}{c}\text { Grafted } \\
\text { plant }\end{array}$ & $\begin{array}{c}\text { Plant } \\
\text { density } \\
\text { (plants/ha) }\end{array}$ \\
\hline $\mathrm{T}_{0}$ & No & No & 3472 \\
$\mathrm{~T}_{0} \mathrm{~B}$ & Yes & No & 3472 \\
$\mathrm{~T}_{1}$ & No & Yes & 2778 \\
$\mathrm{~T}_{2}$ & No & Yes & 2083 \\
$\mathrm{~T}_{3}$ & No & Yes & 1736 \\
\hline
\end{tabular}

Average fruit weight. The average fruit weight obtained from the grafted plants exceeded, in all cases, those obtained from nongrafted plants (Tables 2 and 3). This difference was higher when the grafting was made on 'RS841'. The increase of average fruit weight of grafted plants with respect to nongrafted plants occurred for 'Tri-X 313' as well as 'Sangría', varying from $13 \%$ to $28 \%$.

The average fruit weights of the grafted plants at the different plant densities were statistically similar for each of the two watermelon cultivars during the 2 years and on both rootstocks (Tables 2 and 3 ).

It is important to highlight that the fruits from the nongrafted watermelon plants had similar average fruit weight whether they were grown in MB-treated soil.

The number of fruits $/ \mathrm{m}^{2}$ for ' Tri-X 313' and 'Sangría' showed significant differences between plants grafted on 'RS841' and nongrafted plants both years. On the other hand, fruit numbers on the first year on 'Tri-X 313' and 'Sangría' the second year grafted on 'Shintosa Camelforce' did not show significant differences with nongrafted plants.
Schultheis et al. (2008) obtained higher yield and fruit weight of 'Tri-X 313' grafted on 'Shintosa Camelforce' in comparison with nongrafted plants. Yetisir et al. (2007) and Yetisir and Sari (2004) reported that watermelon grafted on interspecific hybrid of $C$. maxima $\times C$. moschata had increased fruit size. Also, Alan et al. (2007) obtained greater fruit weight in watermelon cv. Crispy grafted on different interspecific hybrids, although only under a plastic tunnel. Miguel et al. (2004) determined that the rootstock 'Shintoza' in a nonfumigated soil had a direct effect on fruit size of 'Reina de Corazones', similar to the size of fruits harvested from grafted plants in soil fumigated with MB.

Yield. The total yield showed highly significant differences between the treatments during the 2 years. The total yield obtained from grafted plants at all tested planting densities was higher than the yield obtained from nongrafted plants irrespective of fumigation, treatments $\mathrm{T}_{0}$ and $\mathrm{T}_{0} \mathrm{~B}$ (Tables 2 and 3 ). In the case of the yield from plants grafted on 'RS841', it exceeded by $66 \%$ and $115 \%$ the yield obtained from nongrafted plants in 2007 and 2008, respectively. In the

Table 2. Average fruit numbers, average fruit weight, and yield for 'Tri-X 313' and 'Sangría' watermelon in the experiments using the 'RS841' rootstock.

\begin{tabular}{lccccccc}
\hline & \multicolumn{3}{c}{ Tri-X 313} & \multicolumn{3}{c}{ Sangría } & Total \\
\cline { 2 - 5 } Treatment & Fruits $/ \mathrm{m}^{2}$ & AFV & $\mathrm{kg} \cdot \mathrm{m}^{-2}$ & Fruits $/ \mathrm{m}^{2}$ & AFV & $\mathrm{kg} \cdot \mathrm{m}^{-2}$ & $\mathrm{~kg} \cdot \mathrm{m}^{-2}$ \\
\hline $\mathrm{T}_{0}$ & $0.75 \mathrm{~b}^{z}$ & $4.34 \mathrm{~b}$ & $3.34 \mathrm{~b}$ & $0.20 \mathrm{ab}$ & $5.80 \mathrm{bc}$ & $1.16 \mathrm{~b}$ & $4.5 \mathrm{bc}$ \\
$\mathrm{T}_{0} \mathrm{~B}$ & $0.67 \mathrm{~b}$ & $4.38 \mathrm{~b}$ & $2.98 \mathrm{~b}$ & $0.16 \mathrm{~b}$ & $5.66 \mathrm{c}$ & $0.94 \mathrm{~b}$ & $3.9 \mathrm{c}$ \\
$\mathrm{T}_{1}$ & $0.99 \mathrm{a}$ & $5.14 \mathrm{a}$ & $5.00 \mathrm{a}$ & $0.33 \mathrm{a}$ & $6.60 \mathrm{a}$ & $2.28 \mathrm{a}$ & $7.3 \mathrm{a}$ \\
$\mathrm{T}_{2}$ & $0.90 \mathrm{a}$ & $5.17 \mathrm{a}$ & $4.57 \mathrm{a}$ & $0.27 \mathrm{ab}$ & $6.51 \mathrm{ab}$ & $2.01 \mathrm{a}$ & $6.6 \mathrm{ab}$ \\
$\mathrm{T}_{3}$ & $0.93 \mathrm{a}$ & $5.22 \mathrm{a}$ & $4.76 \mathrm{a}$ & $0.31 \mathrm{a}$ & $6.87 \mathrm{a}$ & $2.24 \mathrm{a}$ & $7.0 \mathrm{ab}$ \\
$P$ & 0.00 & 0.00 & 0.00 & 0.03 & 0.04 & 0.00 & 0.04 \\
& & & & & & & \\
$\mathrm{~T}_{0}$ & $0.47 \mathrm{~b}$ & $5.08 \mathrm{~b}$ & $2.45 \mathrm{~b}$ & $0.18 \mathrm{~b}$ & $5.50 \mathrm{~b}$ & $1.04 \mathrm{~b}$ & $3.49 \mathrm{~b}$ \\
$\mathrm{~T}_{0} \mathrm{~B}$ & $0.45 \mathrm{~b}$ & $5.03 \mathrm{~b}$ & $2.20 \mathrm{~b}$ & $0.17 \mathrm{~b}$ & $6.19 \mathrm{ab}$ & $1.12 \mathrm{~b}$ & $3.32 \mathrm{~b}$ \\
$\mathrm{~T}_{1}$ & $0.83 \mathrm{a}$ & $6.25 \mathrm{a}$ & $5.10 \mathrm{a}$ & $0.34 \mathrm{a}$ & $7.22 \mathrm{a}$ & $2.35 \mathrm{a}$ & $7.45 \mathrm{a}$ \\
$\mathrm{T}_{2}$ & $0.84 \mathrm{a}$ & $6.54 \mathrm{a}$ & $5.42 \mathrm{a}$ & $0.24 \mathrm{ab}$ & $7.66 \mathrm{a}$ & $1.68 \mathrm{a}$ & $7.11 \mathrm{a}$ \\
$\mathrm{T}_{3}$ & $0.81 \mathrm{a}$ & $6.69 \mathrm{a}$ & $5.35 \mathrm{a}$ & $0.29 \mathrm{a}$ & $7.41 \mathrm{a}$ & $2.03 \mathrm{a}$ & $7.38 \mathrm{a}$ \\
$P$ & 0.00 & 0.00 & 0.01 & 0.02 & 0.04 & 0.00 & 0.00 \\
\hline
\end{tabular}

${ }^{\mathrm{z}}$ Different letters mean significant differences at $P<0.05$.

$\mathrm{AFV}=$ average fruit weight.

Table 3. Average fruit numbers, average fruit weight, and yield for 'Tri-X 313' and 'Sangría' watermelon in the experiments using the 'Shintosa Camelforce' rootstock.

\begin{tabular}{|c|c|c|c|c|c|c|c|}
\hline \multirow[b]{2}{*}{ Treatment } & \multicolumn{3}{|c|}{ Tri-X 313} & \multicolumn{3}{|c|}{ Sangría } & \multirow{2}{*}{$\begin{array}{l}\text { Total } \\
\mathrm{kg} \cdot \mathrm{m}^{-2}\end{array}$} \\
\hline & Fruits $/ \mathrm{m}^{2}$ & AFV & $\mathrm{kg} \cdot \mathrm{m}^{-2}$ & Fruits $/ \mathrm{m}^{2}$ & AFV & $\mathrm{kg} \cdot \mathrm{m}^{-2}$ & \\
\hline \multicolumn{8}{|c|}{$2006-2007$} \\
\hline $\mathrm{T}_{0}$ & 0.47 & $4.25 \mathrm{~b}^{\mathrm{z}}$ & 2.03 & $0.16 \mathrm{~b}$ & $5.51 \mathrm{~b}$ & $0.80 \mathrm{~b}$ & $2.83 \mathrm{~b}$ \\
\hline $\mathrm{T}_{0} \mathrm{~B}$ & 0.40 & $4.10 \mathrm{~b}$ & 1.61 & $0.13 \mathrm{~b}$ & $5.92 \mathrm{~b}$ & $0.75 \mathrm{~b}$ & $2.36 \mathrm{~b}$ \\
\hline $\mathrm{T}_{1}$ & 0.46 & $5.09 \mathrm{a}$ & 2.30 & $0.27 \mathrm{a}$ & $6.82 \mathrm{a}$ & $1.83 \mathrm{a}$ & $4.13 \mathrm{a}$ \\
\hline $\mathrm{T}_{2}$ & 0.39 & $5.14 \mathrm{a}$ & 1.95 & $0.32 \mathrm{a}$ & $6.98 \mathrm{a}$ & $2.18 \mathrm{a}$ & $4.14 \mathrm{a}$ \\
\hline $\mathrm{T}_{3}$ & 0.48 & $5.11 \mathrm{a}$ & 2.44 & $0.26 \mathrm{ab}$ & $6.80 \mathrm{a}$ & $1.72 \mathrm{ab}$ & $4.17 \mathrm{a}$ \\
\hline$P$ & 0.09 & 0.00 & 0.55 & 0.00 & 0.00 & 0.02 & 0.01 \\
\hline \multicolumn{8}{|c|}{ 2007-2008 } \\
\hline $\mathrm{T}_{0}$ & $0.49 \mathrm{~b}$ & $5.48 \mathrm{~b}$ & $2.80 \mathrm{~b}$ & 0.25 & $6.12 \mathrm{c}$ & 1.51 & $4.33 \mathrm{~b}$ \\
\hline $\mathrm{T}_{0} \mathrm{~B}$ & $0.46 \mathrm{~b}$ & $5.46 \mathrm{~b}$ & $2.45 \mathrm{~b}$ & 0.23 & $6.23 \mathrm{bc}$ & 1.51 & $3.96 \mathrm{~b}$ \\
\hline $\mathrm{T}_{1}$ & $0.72 \mathrm{a}$ & $6.16 \mathrm{a}$ & $4.32 \mathrm{a}$ & 0.27 & $7.03 \mathrm{ab}$ & 1.83 & $6.15 \mathrm{a}$ \\
\hline $\mathrm{T}_{2}$ & $0.70 \mathrm{a}$ & $6.10 \mathrm{a}$ & $4.21 \mathrm{a}$ & 0.29 & $6.85 \mathrm{abc}$ & 1.95 & $6.16 \mathrm{a}$ \\
\hline $\mathrm{T}_{3}$ & $0.64 \mathrm{a}$ & $6.35 \mathrm{a}$ & $3.97 \mathrm{a}$ & 0.30 & $7.18 \mathrm{a}$ & 2.10 & $6.07 \mathrm{a}$ \\
\hline$P$ & 0.00 & 0.01 & 0.00 & 0.10 & 0.04 & 0.08 & 0.00 \\
\hline
\end{tabular}

${ }^{\mathrm{z} D i f f e r e n t ~ l e t t e r s ~ m e a n ~ s i g n i f i c a n t ~ d i f f e r e n c e s ~ a t ~} P<0.05$. $\mathrm{AFV}=$ average fruit weight. 
case of the yield obtained from plants grafted on 'Shintosa Camelforce', the total yield exceeded that obtained from nongrafted plants by $60 \%$ and $48 \%$, respectively.

The grafted plants at different densities had similar yield per unit area in the 2 years and on the two rootstocks. Our results are inconsistent with those of Goreta et al. (2005) and Sanders et al. (1999) who showed that yield per unit area increased with planting density in nongrafted watermelon. From the similar yields we obtained at the different plant densities, we deduced that higher yield per plant could be achieved with further decreases in planting density as shown by Goreta et al. (2005) and Sanders et al. (1999).

There are several other reports of increased productivity by grafting watermelon. Yield increases of 3.5 (Salam et al., 2002) and two to 3.5 times have been obtained depending on the rootstock used (Yilmaz et al., 2007). These increases are the result of control of Fusarium oxysporum sp. niveum and the increase in the number and weight of fruits, even with reduction to half the plant density of nongrafted plants.

Authors have suggested that the higher yield obtained from grafted plants is the result of improvement in the nutritional status and higher $\mathrm{CO}_{2}$ and soil water assimilation (Colla et al., 2008; Prioetti et al., 2008), is the result of increases in the production of endogenous hormones (Pulgar et al., 2000; Zijlstra et al., 1994), or is the result of enhanced water and nutrient uptake (Blestos, 2006; Yetisir and Sari, 2004). Ruiz et al. (1997) suggested that the joint action of some or all the previous processes is involved.

The interspecific hybrids of C. maxima $\times$ C. moschata used in this experiment have vigorous root systems; therefore, we would expect that the plants grafted on them should be able to absorb water and nutrients more efficiently than nongrafted plants (Camacho and Fernández, 2000; Huitrón et al., 2007; Lee and Oda, 2003; Miguel et al., 2004). Jifon et al. (2008) showed that keeping favorable water relations is a possible mechanism by which rootstocks with vigorous root systems may tolerate infection without developing watermelon vine decline. Boughalleb et al. (2007) reported that the extension of the production period is another advantage of grafted plants.

These results show that the average fruit weight of watermelon is strongly influenced by grafting, and it is an important component of yield.

Fruit firmness. Although firmness is one of the typical characteristics of the scion, firmness could be affected by several factors, including grafting. Grafting influenced the firmness in a highly significant way. Fruits obtained from grafted plants were firmer than the fruits from the nongrafted plants independent of cultivar, rootstock, or year (Tables 4 and 5). Another study also reports a substantial increase in watermelon firmness from grafted plants (Roberts et al., 2007).

In our experiment, the firmness values in fruits of 'Tri-X 313' fluctuated from 1.63 to $2.33 \mathrm{~kg} \cdot \mathrm{cm}^{-2}$, which was within the values

Table 4. Quality parameters for 'Tri-X 313' and 'Sangría' watermelon from the experiments using the 'RS841' rootstock.

\begin{tabular}{|c|c|c|c|c|}
\hline \multirow[b]{2}{*}{ Treatment } & \multicolumn{2}{|c|}{ Tri-X 313} & \multicolumn{2}{|c|}{ Sangría } \\
\hline & $\begin{array}{l}\text { Firmness } \\
\left(\mathrm{kg} \cdot \mathrm{cm}^{-2}\right)\end{array}$ & $\begin{array}{c}\text { Soluble solids } \\
\left({ }^{\circ} \text { Brix }\right)\end{array}$ & $\begin{array}{l}\text { Firmness } \\
\left(\mathrm{kg} \cdot \mathrm{cm}^{-2}\right)\end{array}$ & $\begin{array}{c}\begin{array}{c}\text { Soluble solids } \\
\left({ }^{\circ} \text { Brix }\right)\end{array}\end{array}$ \\
\hline & & $2006-2007$ & & \\
\hline $\mathrm{T}_{0}$ & $1.83 \mathrm{~b}^{\mathrm{z}}$ & 9.64 & $1.66 \mathrm{c}$ & 9.78 \\
\hline $\mathrm{T}_{0} \mathrm{~B}$ & $1.79 \mathrm{~b}$ & 9.71 & $1.66 \mathrm{c}$ & 8.79 \\
\hline $\mathrm{T}_{1}$ & $2.19 \mathrm{a}$ & 9.78 & $1.86 \mathrm{ab}$ & 9.17 \\
\hline $\mathrm{T}_{2}$ & $2.19 \mathrm{a}$ & 9.57 & $1.82 \mathrm{~b}$ & 9.20 \\
\hline $\mathrm{T}_{3}$ & $2.25 \mathrm{a}$ & 9.78 & $2.00 \mathrm{a}$ & 8.90 \\
\hline$P$ & 0.00 & 0.95 & 0.00 & 0.14 \\
\hline & & $2007-2008$ & & \\
\hline $\mathrm{T}_{0}$ & $1.63 \mathrm{~d}$ & 10.00 & $1.31 \mathrm{c}$ & 9.80 \\
\hline $\mathrm{T}_{0} \mathrm{~B}$ & $1.81 \mathrm{c}$ & 9.89 & $1.49 \mathrm{~b}$ & 9.10 \\
\hline $\mathrm{T}_{1}$ & $2.03 \mathrm{~b}$ & 9.82 & $1.83 \mathrm{a}$ & 9.18 \\
\hline $\mathrm{T}_{2}$ & $2.23 \mathrm{a}$ & 10.25 & $1.83 \mathrm{a}$ & 9.22 \\
\hline $\mathrm{T}_{3}$ & $2.00 \mathrm{~b}$ & 9.99 & $1.84 \mathrm{a}$ & 9.36 \\
\hline$P$ & 0.00 & 0.87 & 0.00 & 0.51 \\
\hline
\end{tabular}

${ }^{\mathrm{z}}$ Different letters mean significant differences at $P<0.05$.

Table 5. Quality parameters for 'Tri-X 313' and 'Sangría' watermelon from the experiments using the 'Shintosa Camelforce' rootstock.

\begin{tabular}{|c|c|c|c|c|}
\hline \multirow[b]{2}{*}{ Treatment } & \multicolumn{2}{|c|}{ Tri-X 313} & \multicolumn{2}{|c|}{ Sangría } \\
\hline & $\begin{array}{l}\text { Firmness } \\
\left(\mathrm{kg} \cdot \mathrm{cm}^{-2}\right)\end{array}$ & $\begin{array}{l}\text { Soluble solids } \\
\left({ }^{\circ} \text { Brix }\right)\end{array}$ & $\begin{array}{l}\text { Firmness } \\
\left(\mathrm{kg} \cdot \mathrm{cm}^{-2}\right)\end{array}$ & $\begin{array}{c}\text { Soluble solids } \\
\left({ }^{\circ} \text { Brix }\right)\end{array}$ \\
\hline \multicolumn{5}{|c|}{$2006-2007$} \\
\hline $\mathrm{T}_{0}$ & $1.87 \mathrm{c}^{\mathrm{z}}$ & 9.52 & 1.73 & 9.09 \\
\hline $\mathrm{T}_{0} \mathrm{~B}$ & $1.88 \mathrm{c}$ & 9.21 & 1.71 & 8.81 \\
\hline $\mathrm{T}_{1}$ & $2.13 \mathrm{bc}$ & 9.52 & 1.76 & 8.65 \\
\hline $\mathrm{T}_{2}$ & $2.03 \mathrm{ab}$ & 9.63 & 1.87 & 8.86 \\
\hline $\mathrm{T}_{3}$ & $2.25 \mathrm{a}$ & 9.67 & 1.87 & 9.25 \\
\hline$P$ & 0.00 & 0.44 & 0.07 & 0.41 \\
\hline \multicolumn{5}{|c|}{$2007-2008$} \\
\hline $\mathrm{T}_{0}$ & $1.89 \mathrm{c}$ & 10.51 & $1.55 \mathrm{c}$ & 10.00 \\
\hline $\mathrm{T}_{0} \mathrm{~B}$ & $1.89 \mathrm{c}$ & 10.03 & $1.53 \mathrm{c}$ & 9.85 \\
\hline $\mathrm{T}_{1}$ & $2.20 \mathrm{ab}$ & 9.94 & $1.70 \mathrm{~b}$ & 9.22 \\
\hline $\mathrm{T}_{2}$ & $2.33 \mathrm{a}$ & 9.82 & $1.68 \mathrm{~b}$ & 9.14 \\
\hline $\mathrm{T}_{3}$ & $2.11 \mathrm{~b}$ & 10.08 & $1.92 \mathrm{a}$ & 9.42 \\
\hline$P$ & 0.00 & 0.46 & 0.00 & 0.12 \\
\hline
\end{tabular}

${ }^{\mathrm{z}}$ Different letters mean significant differences at $P<0.05$.

considered to be "crunchy" watermelon (Camacho and Fernández, 2000).

If we compare the firmness of the two cultivars in the treatments of nongrafted plants with and without $\mathrm{MB}\left(\mathrm{T}_{0}\right.$ and $\left.\mathrm{T}_{0} \mathrm{~B}\right)$, there were no statistical differences in the 'Tri-X 313', but there were differences in 'Sangría'; however, the highest firmness was lower than the firmness for the fruits from grafted plants.

Content of soluble solids. During the 2 years, the content of soluble solids was unaffected by grafting or fumigation (Tables 4 and 5). These results were similar to those observed by Colla et al. (2008), Miguel et al. (2004), Roberts et al. (2007), and Schultheis et al. (2008) in watermelon and by Crino et al. (2007) in melon.

Alan et al. (2007) and Miguel et al. (2004) studied watermelon grafted on rootstocks similar to those of this experiment and also reported that there were no detrimental effects on quality. The average value of soluble solids for 'Tri-X 313' was $9.8^{\circ}$ Brix, whereas the average value of 'Sangría' was $9.3^{\circ}$ Brix.

Our results are consistent with those of Hassell and Memmott (2008) who showed that grafting increases watermelon flesh firmness without adverse effects on sugar content. Grafting increases vigor and crop yield without harmful effects on quality; therefore, grafting is a useful for a sustainable horticulture in a future with the loss of MB (Colla et al., 2008; Sakata et al., 2007).

\section{Conclusions}

The total watermelon yield obtained on the rootstocks 'RS841' and 'Shintosa Camelforce' in soil without fumigation with $\mathrm{MB}$ exceeded by $115 \%$ and $58 \%$, respectively, the total yield obtained with nongrafted plant in a soil fumigated with MB. Therefore, grafting can be considered as an alternative to fumigation.

With the use of grafted watermelon plant, planting density can be reduced up to $50 \%$ compared with the plant density used with nongrafted plants. Grafting enhanced average fruit size. Nongrafted plants grown in soils infested with MNSV and Olpidium bornovanus did not show significant differences in yield obtained with or without MB fumigation. Fruits from grafted plants had greater firmness than those from nongrafted plants without affecting the content of soluble solids. 


\section{Literature Cited}

Alan, O., N. Ozdemir, and Y. Günem. 2007. Effect of grafting on watermelon plant growth, yield and quality. J. Agron. 6:362-365.

Besri, M. 2008. Cucurbits grafting as alternative to methyl bromide for cucurbits production in Morocco. Proc. Annual International Research Conference on Methyl Bromide Alternatives and Emissions Reductions. Orlando, FL. p. 60.

Blestos, F.A. 2006. Grafting and calcium cyanamide as alternatives to methyl bromide for greenhouse eggplant production. Scientia Hort. 107:325-331.

Boughalleb, N., N. Tarchoun, A. El Mabarki, and M. El Mahjoub. 2007. Resistance evaluation of nine cucurbit rootstocks and grafted watermelon (Citrullus lanatus L.) cultivars against fusarium wilt and fusarium crown and root rot. J. Plant Sci. 2:102-107.

Camacho, F. and E.J. Fernández. 2000. El cultivo de sandia apirena injertada bajo invernadero en el litoral mediterráneo español. Caja Rural de Almería, Almería, Spain.

Camacho, F. and J.C. Tello. 2006. Control de patógenos telúricos en cultivos hortícolas intensivos. Ediciones Agrotécnicas, Madrid, Spain.

Colla, G., Y. Rouphael, M. Cardarelli, O. Temperini, E. Rea, A. Salerno, and F. Pierandrei. 2008. Influence of grafting on yield and fruit quality of pepper (Capsicum annuum L.) grown under greenhouse conditions. Acta Hort. 782:359-364.

Crino, P., Ch. Lo Bianco, Y. Rouphael, G. Colla, F. Saccardo, and A. Paratorre. 2007. Evaluation of rootstock resistance to fusarium wilt and gummy stem blight and effect on yield and quality of a grafted 'Inodorus' melon. HortScience 42:521-525.

Cushman, K.E. and J. Huan. 2008. Performance of four triploid watermelon cultivars grafted onto five rootstock genotypes: Yield and fruit quality under commercial growing conditions. Acta Hort. 782:335-342.

Davis, A.R., P. Perkins Veazie, Y. Sakata, S. Lopez-Galarza, J.V. Maroto, S. Lee, Y. Huh, Z. Sun, A. Miguel, S.R. King, R. Cohen, and J.M. Lee. 2008. Cucurbit grafting. Crit. Rev. Plant Sci. 27:50-74

Edelstein, M., R. Cohen, Y. Burger, and S. Shriver. 1999. Integrated management of sudden wilt in melons, caused by Monosporascus cannonballus, using grafted and reduced rates of methyl bromide. Plant Dis. 83:1142-1145.

FAOSTAT. 2007. 17 Apr. 2009. <http://faostat.fao. org/site/567/default.aspx>.

Goreta, S., S. Perica, G. Dumicic, L. Bucan, and K. Zanic. 2005. Growth and yield of watermelon on polyethylene mulch with different spacing and nitrogen rates. HortScience 40:366-369.

Hassell, R., J. Schultheis, S. Olson, T. Kelley, P. Perkins-Veazie, G. Miller, and F. Memmott. 2008. Yield and quality of two seedless watermelon cultivars grafted on eight rootstocks tested at five locations within the southeastern United States. Research Report 2007. National Watermelon Association Research. 10 July 2008. $<$ http://www.nationalwatermelonassociation. com/scientific_research.php>.

Hassell, R.L. and F. Memmott. 2008. Grafting methods for cucurbit production. HortScience 43:1677-1679.

Huitrón, M.V., M. Díaz, F. Diánez, and F. Camacho. 2007. The effect of various rootstocks on triploid watermelon yield and quality. J. Food. Agr. Environ. 5:344-348.

Jifon, J.L., K.M. Crosby, D.I. Leskovar, and M. Miller. 2008. Possible mechanisms of resistance to vine decline diseases in grafted watermelons. Acta Hort. 782:329-334.

King, S.R., A.R. Davies, B. LaMolinare, W. Liu, and A. Levi. 2008. Grafting for disease resistance. HortScience 43:1673-1676.

Lee, J.M. 2003. Advances in vegetable grafting. Chronica Hort. 43:13-19.

Lee, J.M. and M. Oda. 2003. Grafting of herbaceous vegetable and ornamental crops. Hort. Rev. (Amer. Soc. Hort. Sci.) 28:61-124.

Miguel, A. 2005. Use of grafted cucurbits in mediterranean region as an alternative to methyl bromide. Proc. Fifth International Conference on Alternatives to Methyl Bromide. European Commission, Lisbon, Portugal. p. 75-80.

Miguel, A., J.V. Maroto, A. San Bautista, C Baixauli, V. Cebolla, B. Pascual, S. López, and J.L. Guardiola. 2004. The grafting of triploid watermelon is an advantageous alternative to soil fumigation by methyl bromide for control of Fusarium wilt. Scientia Hort. 103:9-17.

Passam, H. 2003. Use of grafting makes comeback. Fruit Veg Tech. 3:7-9.

Prioetti, S., Y. Rouphael, G. Colla, M. Cardarelli, M. De Agazio, M. Zacchini, E. Rea, S. Moscatello, and A. Battistelli. 2008. Fruit quality of miniwatermelon as affected by grafting and irrigation regimes. J. Sci. Food Agr. 88:1107-1114.

Pulgar, G., G. Villora, D.A. Moreno, and L. Romero. 2000. Improving the mineral nutrition in grafted watermelon plants: Nitrogen metabolism. Biol. Plant. 43:607-609.

Rivero, R.M., J.M. Ruiz, and L. Romero. 2003. Role of grafting in horticultural plants under stress conditions. J. Food Agr. Environ. 1:70-74.

Roberts, W., B.W. Bruton, W. Fish, and M.J. Taylor. 2007. Using grafted transplants in watermelon production. Proc. 2007 Southeast Regional Veg. Conf. Savannah, GA. p. 33-36.

Ruiz, J.M., A. Belakbir, I. López-Cantarero, and L. Romero. 1997. Leaf-micronutrient content and yield in grafted melon plants. A model to evaluate the influence of rootstock genotype. Scientia Hort. 71:227-234.

Sakata, Y., T. Ohara, and M. Sugiyama. 2007. The history and present state of the grafting in Japan. Acta Hort. 731:159-170.

Salam, M.A., A.S.M.H. Masum, S.S. Chowdhrury, M. Dhar, M.A. Saddeque, and M.R. Islam. 2002. Growth and yield of watermelon as influenced by grafting. J. Biol. Sci. 2:298299.

Sanders, D.C., J.D. Cure, and J.R. Schultheis. 1999. Yield response of watermelon to planting density, planting pattern, and polyethylene mulch. HortScience 34:1221-1223.

Schultheis, J., R. Hassell, T. Kelley, R. Kumar, S. Olson, and T.C. Wehner. 2008. Grafted watermelon: Evaluation of planting density for high yield, 2008 results. National Watermelon Association. 4 May 2009. <http://www.national watermelonassociation.com/pdfs/Grafted $\% 20$ Watermelon\%20article.pdf $>$

Sigüenza, C., M. Schoschow, T. Turini, and A. Ploeg. 2005. Use of Cucumis metuliferus as a rootstock for melon to manage Meloidogyne incognita. J. Nematol. 37:276-280.

Yetisir, H., S. Kurt, N. Sari, and F.M. Took. 2007. Rootstock potential of Turkish Lagenaria siceraria germplasm for watermelon: Plant growth, graft compatibility, and resistance to fusarium. Turk. J. Agr. For. 31:381-388.

Yetisir, H. and N. Sari. 2004. Effect of hypocotyl morphology on survival rate and growth of watermelon seedlings grafted on rootstocks with different emergence performance at various temperatures. Turk. J. Agr. For. 28:231237.

Yilmaz, S., M. Göcmen, A. Ünlü, A.F. Firat, K Aydinsakir, S. Cetinkaya, M. Kuzgun, M.A. Celikyurt, B. Sayin, and I. Celik. 2007. Grafting as an alternative to $\mathrm{MB}$ in vegetable production in Turkey. Proc. Annu. Intl. Res. Conf. Methyl Bromide Alternatives and Emissions Reductions. Methy Bromide Alternatives Outreach. San Diego, CA. p. 60. 10 July 2008. <http://mbao. org/2007/Proceedings/060YilmazSGraftingasa nalternativetoMBisveget.pdf $>$.

Zijlstra, S., S.P.C. Groot, and J. Jansen. 1994 Genotype variation of rootstocks for growth and production in cucumber; possibilities for improving the root system by plant breeding. Sci. Hort. 56:185-196. 